\title{
On the choice of parameters for the weighting method in vector optimization
}

\author{
L. M. Graña Drummond • N. Maculan • \\ B. F. Svaiter
}

Published online: 16 June 2007

(C) Springer-Verlag 2007

\section{Erratum to: Math. Program., Ser. B DOI 10.1007/s10107-006-0071-7}

Unfortunately, due to a publisher mistake the spelling of the author's name was incorrect in the online version. The correct name should read L.M. Graña Drummond.

The online version of the original article can be found under doi:10.1007/s10107-006-0071-7.

L. M. Graña Drummond ( $\square)$

Faculdade de Administração e Ciências Contábeis, FACC-UFRJ, Pasteur 250,

Rio de Janeiro, RJ, CEP 22290-240, Brazil

e-mail: lmgd@facc.ufrj.br

N. Maculan

Programa de Engenharia de Sistemas de Computação, COPPE-UFRJ, CP 68511,

Rio de Janeiro, RJ, CEP 21945-970, Brazil

e-mail: maculan@cos.ufrj.br

B. F. Svaiter

Instituto de Matemática Pura e Aplicada (IMPA), Estrada Dona Castorina 110,

Rio de Janeiro, RJ, CEP 22460-320, Brazil

e-mail: benar@impa.br 